\title{
TV/Series
}

$7 \mid 2015$

Le Pilote et la chute

\section{I, Claudius (1976) vs Rome (2005), or Ancient Rome revisited by television}

Isabelle Roblin

\section{(2) OpenEdition \\ 1 Journals}

\section{Electronic version}

URL: http://journals.openedition.org/tvseries/295

DOI: $10.4000 /$ tvseries.295

ISSN: 2266-0909

\section{Publisher}

GRIC - Groupe de recherche Identités et Cultures

\section{Electronic reference}

Isabelle Roblin, «I, Claudius (1976) vs Rome (2005), or Ancient Rome revisited by television », TV/Series [Online], 7 | 2015, Online since 01 June 2015, connection on 20 April 2019. URL : http:// journals.openedition.org/tvseries/295; DOI : 10.4000/tvseries.295

\section{(ब) $(\oplus \Theta$}

TV/Series est mis à disposition selon les termes de la licence Creative Commons Attribution - Pas d'Utilisation Commerciale - Pas de Modification 4.0 International. 


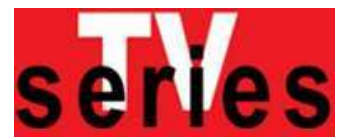

\title{
I, Claudius (1976) vs Rome (2005), or Ancient Rome revisited by television
}

Isabelle RoBLIN

\begin{abstract}
On top of its arguably philosophical and/or pedagogical intentions, the representation of Antiquity in literature and film has always conveyed much about the ideology of the periods in which it was written or filmed. For example, the social and cultural background radically altered between two critically acclaimed BBC television series about Ancient Rome: the 1976 I, Claudius, an adaptation of Robert Graves' novels, and the 2005 first season of Rome, a BBC-HBO coproduction. Whereas I, Claudius is set almost exclusively within the ruling Imperial family and considers history as that of "great men", Rome on the other hand clearly plays on the fascination for class distinctions and more specifically on the division between Patricians and Plebeians. This conception of Roman history is also built into Rome's structure, as the lives of two common soldiers are intertwined with major historical events and characters, giving a fresh perspective on well-known occurrences. The way in which sexuality and religion are dealt with in both series is also quite relevant to the times in which they were filmed but on the other hand, their representation of the role of women as, essentially, mothers, seems to conform to the same stereotype.
\end{abstract}

Par-delà les intentions philosophiques et/ou idéologiques, la manière dont l'Antiquité est représentée dans la littérature ou au cinéma a toujours été révélatrice de l'idéologie de la période où elle a été écrite ou filmée. Ainsi, le contexte social et économique a beaucoup évolué entre deux séries télévisées à succès ayant pour sujet la Rome antique : I, Claudius (BBC, 1976), adaptation des romans de Robert Graves, et Rome (BBC-HBO 2005). Alors que l'action de I, Claudius se situe presque exclusivement au sein de la famille impériale, Rome tire clairement parti de la fascination pour les différences de classe, et plus particulièrement de la division entre patriciens et plébéiens. Cette conception de l'histoire romaine est inscrite dans la structure même de Rome, où la vie de deux simples soldats est mêlée aux événements et personnages historiques, donnant ainsi une perspective nouvelle sur les hauts faits célèbres. La manière dont la sexualité et la religion sont traitées dans les deux séries est également indissociable de l'époque à laquelle elles ont été tournées mais d'un autre côté leur représentation du rôle des femmes, essentiellement en tant que mères, semble relever du même stéréotype.

ncient Rome has been a popular topic for the cinema ever since
peplum films started flooding the silver screens in the 1950s.
Television series dealing with the subject were however few and
far between. Among the rare examples, The Caesars, produced in 1968
by Granada TV for the ITV network in Britain, and I, Claudius, a 13-
episode, 1976 BBC adaptation of Robert Graves' 1934 historical novels
I, Claudius and Claudius the God, which has become one of the
corporation's most successful drama serials of all time, both critically
and commercially. Indeed, rating surveys assessed the average
audience of its original airing in 1976 at $2,500,000$ viewers per
episode'. It was made relatively cheaply, an hour of broadcast material

${ }^{1}$ BBC Handbook 1977 Incorporating the Annual Report and Accounts 1975-76, London, 1977 , p. 47 . In 2000 it was ranked $12^{\text {th }}$ in the British Film Institute's list, drawn up by industry professionals, of the "100 Greatest British Television Programmes" and in 2007 it made the list of Time magazine's "Best TV Shows of All-TIME" (James Poniewosik, 
reportedly costing at the time on average $£ 60,000$, and "the serial was shot entirely in the studio on a budget of approximately two million dollars ${ }^{2}$ ". The cast and the sets were limited, giving the series a theatricality which is reinforced by the frequent use of monologues ${ }^{3}$ and "long, 'unblinking eye' camera shots, occasionally trundling in for close-ups in moments of high drama, with very few cuts4". I, Claudius went on to win three BAFTA awards in 1977 (for Best Actor, Best Actress and Best Design) and it was subsequently broadcast in the United States as part of PBS' Masterpiece Theatre and in France in 1978, and then again in 1982 and 1986. It was reshown in 1978 and 1986 on $\mathrm{BBC}_{1}$ and its latest rerun was on $\mathrm{BBC}_{4}$ from March to May 2013. Recently, $\mathrm{HBO}$ has teamed with $\mathrm{BBC} 2$ to acquire the rights to develop a remake of the series 5 .

I, Claudius considers the history of the early Roman Empire through the eyes of the fourth eponymous emperor, who is of course well-known in British history for his role in the conquest and Romanisation of Britain, which is often referred to in the series. For example, in the penultimate episode ("A God in Colchester") Claudius learns that the Britons have made him a God and dedicated a temple to him in Colchester. Each of the thirteen episodes chronicles the bloody events which eventually led to his unexpected accession (in 41 A.D.) and death (in 54 A.D.). Jack Pulman, who scripted the whole series, privileged literary devices for his adaptation 6 . The narrational structure of the episodes has been analysed in depth by Sandra Joshel. Each episode starts with a flashback as the audience watches the older Claudius writing his memoirs "in the interior rooms of the palace: his

http://entertainment.time.com/2007/09/06/the-100-best-tv-shows-of-all-time/slide/iclaudius/, consulted in October 2013

${ }^{2}$ Sandra Joshel, "I, Claudius: Projection and Imperial Soap Opera," in Imperial Projections: Ancient Rome in Modern popular Culture, Baltimore and London, John Hopkins UP, 2001, p. 155, note 3 .

3 For example, "a scene worth mentioning from the original" in episode 7 "is the devastating 10-minute confession from Lollia", a traditional Roman matron played by Isabel Dean, "that she cannot live with the memory of being abused by Tiberius. Her subsequent suicide is made all the more shocking by the eloquence of her speech." Ben Lawrence, "I, Claudius: what $\mathrm{HBO}$ can learn from the BBC classic":

http://www.telegraph.co.uk/culture/tvandradio/10096739/I-Claudius-what-HBO-canlearn-from-the-BBC-classic.html, consulted in September 2013.

4 "Why I, Claudius should be remade," http://www.guardian.co.uk/tv-and-radio/ tvandradioblog/2011/jun/13/i-claudius-hbo-remake, consulted September 2013.

5 See for example Mark Fleming's article, "HBO, BBC2 Make Deal To Turn Robert Graves Novel 'I, Claudius' Into Epic Miniseries," June 10, 2011, http://www.deadline .com/2011/06/hbo-bbc2-new-make-deal-to-turn-robert-graves-novel-i-claudius-into-epicminiseries/, consulted in September 2013.

${ }^{6} \mathrm{He}$ also wrote in a few private jokes: for example "in Claudius's speech to the Senate in the final episode, Claudius prophesies that 'the man who dwells by the pool shall open graves, and the dead shall live again'. This is a reference to the scriptwriter, Jack Pulman, and a pun on the book's author, Robert Graves", http://en.wikipedia.org/wiki/ I, Claudius \%28TV_series\%29, consulted in November 2013. 
bedroom, private study, and even toilet7" and reminiscing, sometimes in voiceover, about his own amazing destiny. The story of his imperial family, which in fact overlaps the history of Rome, "becomes the spectacle 8 ". Moreover,

since all viewers ever see of the empire is its ruling family, and since empire is narratively contained within the family in the form of objects, marginalized subject people, and talk, the family stands for the empire it rules. The imperial family becomes a metonymy for Rome, and Rome means empire9.

Thirty years later, another series, Rome, a HBO/BBC/RAI coproduction in two seasons, of respectively twelve and ten episodes, was going to alter radically and even challenge this vision of both the history of Rome and Roman society. Not only had viewers' mentalities considerably changed in a generation, not only had technical innovations, in terms of lighting and computerisation for example, revolutionised the filming process, but the broadcasting conditions on television, especially in the United States, had been totally transformed during these three decades. The appearance of Premium Cable TV, and particularly of HBO (Home Box Office, an operating subsidiary of Time Warner), free from the explicit or implicit censorship of family oriented networks such as $\mathrm{ABC}$ or CBS as well as from the financial pressure of the announcers thanks to its 30 million plus subscribers, made it possible for the screenwriters and producers to take a much more radical and (arguably) creative approach to the making of series, especially in the way sexuality, for example, is presented. The first season, with its stunning costumes and lavish settings (most scenes were shot in the legendary Cinecitta studios in Rome) cost more than US $\$ 100$ million for the twelve, one-hour long episodes, and is regarded as being one of the most expensive in the history of television. It was hugely popular in the United States, with a total weekly audience exceeding seven million viewers for each episode ${ }^{10}$. When aired in the United Kingdom, the first episode attracted 6.6 million viewers but the figures declined in later episodes and "only" 3 million spectators watched the season finale ${ }^{11}$. It won numerous television nominations and awards, among which four Emmys in 2006, but the series ended with the second season (out of the planned five) due to cost.

As in I, Claudius, the first season of Rome is set within a traditional historical framework: it starts with Caesar's victory over the

\footnotetext{
7 Joshel, p. 139.

${ }^{8}$ Joshel, p. 120

9 Joshel, p. 136

${ }^{10}$ Ryan Parsons, "HBO Wants More ROME", CanMag, September 13, 2005, http:/ www. canmag. com/news/4/ 21/1963, accessed in November 2013.

${ }^{11}$ Jason Deans, "Rome's bloody climax wins 3m", The Guardian, January 5, 2006, http// www.theguardian.com/media/2006/jan/05/overnights, consulted November 2013.
} 
Gaulish leader Vercingetorix, in 52 B.C. and ends with Caesar's assassination in 44 B.C. However, one of its most innovative ideas is to provide a double viewpoint on this representation of the end of the Republic. Indeed, unlike I, Claudius, it focuses on the lives not only of well-known members of the aristocracy such as Caesar or Antony but also of two ordinary Plebeian Romans, Titus Pullo and Lucius Vorenus who, at the beginning of the series, are legionaries in Caesar's army and who, like most war veterans throughout history, find it difficult to readapt to civilian life after having spent eight years in the army. They too are to a certain extent historical characters, for the exploits of two centurions bearing those names are briefly mentioned by Caesar in his account of the Gallic War (book 5, chapter 44) as examples of a rather foolish but gallant rivalry. In the series "their characters are dramatized, but the world in which they're moving and the context in which they exist can be fleshed out with historical detail ${ }^{12}$." Thanks to their inclusion in the story, the viewer will have multiple points of view on the related events, which will no longer be seen exclusively from the Imperial family's standpoint ${ }^{13}$.

Thus both series were very successful both in terms of audience ratings and critical acclaim. This is probably due partly to the quality of the acting, especially in I, Claudius, and of the filming and photography in Rome. However, they differ greatly in the way history, religion and sexuality are represented even though there are striking similarities in the way women are portrayed in this male-dominated society.

In I, Claudius the credits, showing the head of Derek Jacobi, who played the title role, as a classic Roman mosaic of Emperor Claudius, with a snake slithering across it (see plate 1), as the title appears on the screen, followed by the names of the actors, unambiguously reveal a view of history as made by "great men":

\footnotetext{
${ }^{2}$ Executive producer and screenwriter Bruno Heller in the Rome (1st season) DVD bonus. ${ }^{13}$ See Vivien Bessières, “Rome, Sweet Rome': L'idée américaine du foyer dans la série Rome”, Les séries américaines. La société réinventée ?, Paris, L'Harmattan, 2013, p. 122 : "Une chose manquait à $I$, Claudius par rapport à une série classique américaine comme Rome : la multiplicité des points de vue. Le point de vue était essentiellement celui de Claude [...]. À l'instar du péplum de cinéma, la série ne descendait jamais dans la rue ou pour de courtes excursions vite oubliées. Tout se passait dans la famille impériale, à l'intérieur des murs du Palais [...]. Dans Rome, le point de vue sera disséminé aux quatre coins de la Ville et le foyer ne sera plus seulement le foyer impérial, qui coïncide avec la nation, mais aussi le foyer familial”.
} 


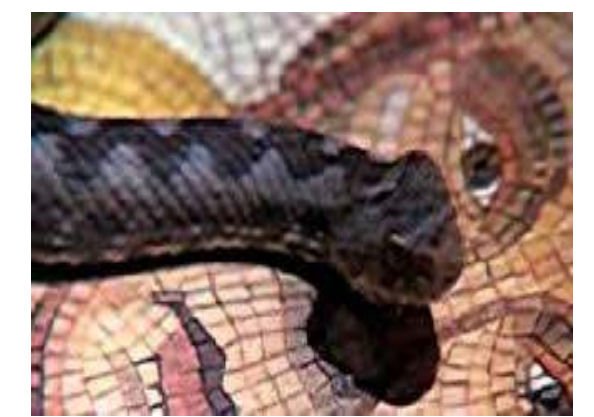

Plate 1: I, Claudius credits (source: mcwetboy.net)

In Rome, the importance given to the "common people" 14 " living in the "mean streets 15 " of the City, as a counterpoint to the aristocrats in their marble villas and palaces, is also obvious from the very beginning. The opening credits are a manifesto to the version of Roman society the series is putting forward ${ }^{16}$. They start with a mosaic, as in I, Claudius, perhaps as a sort of homage to the previous series. However, this mosaic, inspired by a famous one found in Pompeii ${ }^{17}$, is animated and no longer static and shows a skull balanced on a butterfly, itself balanced on a wheel: it is "an allegory of the transitiveness of good fortune ${ }^{18}$ " and the skull itself is a memento mori, "a reminder that all human glory is destined to be ephemeral because everyone is going to die ${ }^{19}$." Another animated mosaic of the Gorgon or Medusa head with serpents is also shown (see plate 2):

\footnotetext{
${ }^{14}$ I use the term in a positive, more American, way, as Walt Whitman for one used it

15 Raymond Chandler's famous description of the hard-boiled detective in Dashiell Hammet's crime novels in "The Simple Art of Murder," The Atlantic Monthly, December 1944, p. 59.

${ }^{16}$ For a detailed description and analysis of the credits, see Julie Gallego, "Jules César au secours des scénaristes américains : l'incipit de la série Rome,” Entre la fiction, les faits, et le réel, TV/Series \#1, juin 2012.

${ }^{17}$ This $1^{\text {st }}$ century mosaic can be seen at the Naples National Archeological Museum.

${ }^{18}$ Audio commentary of episode 1 on the first DVD of the first season of Rome.

${ }^{19}$ Ibid.
} 


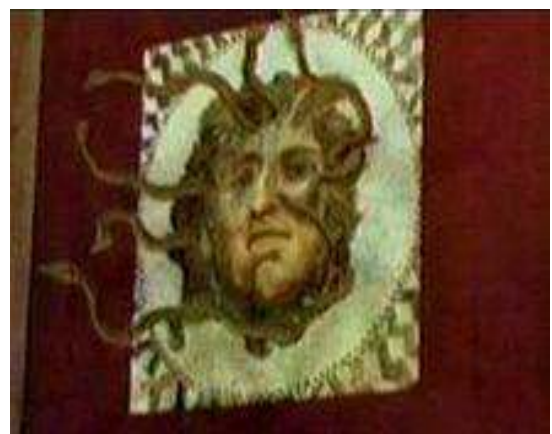

Plate 2: Rome, Gorgoneion from credits (1st season) (source: answers.com)

Then various traditional myths of Rome are played out using cartoonlike graffiti - the popular art form par excellence - as anonymous passers-by go about their business and as the actors' names appear on the screen: Romulus and Remus, the Capitoline geese for example, but also some Latin words and expressions ${ }^{20}$, summing up Roman attitudes to life and death (mortem, vita, pax, arma). Then the word ROME becomes visible on the screen (see plate 3 ), at the very end: it is clearly not Caesar or Pompey but the City itself who is the main character:

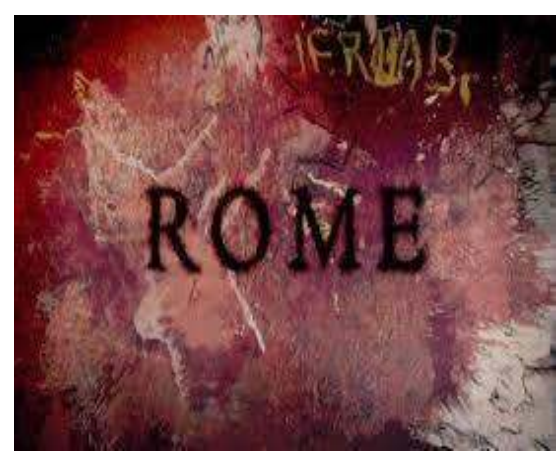

Plate 3. Rome, title screen credits (1st season) (source: en.wikipedia.org)

The credits show "a very different version of Rome from that you normally see on screen: the sense of the number of people" (according

${ }^{20}$ Graffiti are going to play an important part in the series, especially in episode 5 when Atia organizes a smear campaign against her rival Servilia and her lover Caesar by having very explicit and crude sex graffiti and inscriptions (such as "Servilia Caesaris fellator" which, as one internaut pointed out, is self-explanatory even if you don't know any Latin) drawn on the walls of the city. http://glaukopidos.blogspot.fr/2005/09/hbos-rome-ep-5.html, consulted September 2013. 
to Jonathan Stamp, the consultant historian for the series, possibly as many as a million people lived in Rome at that time):

[I]t's colorful and painted, cosmopolitan as well, with people from all over the world, incredibly polyglot. [...] It is important to divest yourself of 'HollyRome', which is the vision we've always got from the movies and try to completely rethink that. [...] You could put a modern Indian city in its place, Calcutta or Bombay, with that immense mass of people there, brighter colors, the sense of smell and noise and business ${ }^{21}$.

The production team thus purposely chose to question and undermine the traditional, stereotypical representations of ancient Rome. More generally, "the publicity material constantly underscores how their Rome differentiates itself from the other representations of the city in order to be as historically accurate as possible ${ }^{22}$ ". One consequence of this search for verisimilitude is the variety of accents heard in this series, which is a multinational co-production (American, British and Italian). As is still the case in Britain today, accents are one of the most important markers of social class and represent the differences in wealth and social status of the characters, from the well-taught Patricians to the uneducated Plebeians. They also stand for the diversity of Rome, from Kevin McKidd's slight Scottish accent (reportedly "toned down after the Hollywood executives found [it] too strong for an American audience ${ }^{23}$ ") to the heavily accented English of some of the Italian extras. In that respect, the contrast with the very R.P. delivery of the actors in I, Claudius, including the young Jewish prince Herod Agrippa (played by James Faulkner), who in episode 3 is complimented by Antonia for his knowledge of the Roman imperial family and mastery of Latin ("How well he speaks Latin", she exclaims in perfect BBC English), is striking, but also logical since in I, Claudius most characters are members of the Imperial family, or at least belong to the ruling classes.

This approach is also to be found in the way history is regarded. Even if the Claudius of the series, in keeping with Robert Graves', is depicted as a sort of "closet republican", yearning in secret for the end of the Imperial rule, which he sees as a form of tyranny, and the return

${ }^{21}$ Bruno Heller's comment on the bonus DVD.

${ }^{22}$ Sylvaine Bataille, “Haunted by Shakespeare: HBO's Rome," Television Shakespeare. Essays in honour of Michèle Willems, Mont-Saint-Aignan, Publications des Universités de Rouen et du Havre, 2008, p. 220. She further remarks that "for all their advertising on the authenticity of the series' depiction of Rome, the creators did not go so far as to write the dialogues in Latin, and stopped short of imitating Mel Gibson's Passion of the Christ (2004), shot entirely in Aramaic" (p. 229), even though they sprinkled the dialogues "with a fair amount of Latin words, such as names of places, gods or mythological creatures, and idiomatic expressions" (p. 231) as well as Shakespearian-sounding insults and metaphors (p. 233-236). I for one agree with her when she writes that series like Rome combine "popular conventions with scholarly references," raise "the interest of a varied audience", and create "a sense of shared culture," p. 246, 247.

${ }^{23}$ Ibid. 
to the old values of the Republic, the Populus Romanus motto is conspicuously absent from the series. Indeed "the people" only make a brief appearance in one or two scenes in which an angry but unorganised mob, represented by a dozen or so extras, is shown shouting and throwing mud (or worse) at members of the Imperial family (at Tiberius and Livia, for example, in episode 1). In fact, "television viewers spend most of their thirteen hours in Rome within the imperial palace: on television, the territory of the Roman empire becomes a series of domestic spaces ${ }^{24}$ ".

On the contrary in Rome the opposition between Patricians (like Brutus or Cato, both pictured as snobs) and Plebeians is central to the plot, with Caesar (himself a Patrician...) relying on the people - and his legions - for much of his power base, even if the electoral system is seen as totally corrupt (in episode 2 for example) and democracy as a gigantic fraud. Perhaps the most striking but also ironic example of the importance given in the series to ordinary people is to be found in the title of the second episode, "How Titus Pullo Brought Down the Republic": it is the Plebeian Pullo's gambling related troubles which will unwittingly set in motion a series of events eventually leading to the civil wars between Caesar and Pompey, and then between Antony and Octavian, and ensure in the end Octavian-Augustus' rise to supreme and absolute power with its corollary, the demise of the Republic.

The demythologising of great men and the rehabilitation of common people are part of the strategy used by the series' director to change the viewers' perspective on history, at times literally. Caesar's triumph, for example (episode 10),

is first shown from the point of view of Vorenus's younger daughter, who is so small she can only see bits and pieces of the spectacle before she is hauled up onto the base of a statue. Only then does the camera pan across the triumph and the cheering crowd 25 .

In the same vein, the screenwriter deliberately omitted some of the stereotyped historical phrases traditionally attributed to Caesar: for instance the crossing of the Rubicon (episode 5), often presented as a momentous event, is kept very low-key and Caesar is never heard saying "the die is cast" or "alea jacta est", nor does he say "You, too, Brutus?" or "Et tu, Brute?" when he is assassinated (episode 12). For Sylvaine Bataille however, there are occasional, albeit veiled, references to the famous citations and she quotes in particular the "Et tu, Brute" Caesar "does not say when he dies" in the last episode of Season 1 of Rome but "comes back in disguise" in the first episode of Season 2 "after the assassination, at the end of a discussion among the

24 Joshel, p. 132

${ }^{25}$ Bataille, p. 225 
conspirators about whether they should kill Antony. When he sees that Servilia disagrees with him and concurs with Cassius and the others, Brutus asks 'You too, mother? 26"', a playful hint for the benefit of the more classically minded part of the audience.

The deliberate and anachronistic choice in Rome of representing Roman society as bipolar, opposing wealthy Patricians and poor Plebeians ${ }^{27}$ and ignoring the Equestrian order altogether (as is also the case in I, Claudius), is typical of a desire to simplify for the average viewer a complex reality where Patricians, Equestrians and rich Plebeians actually shared much of the political power ${ }^{28}$. This dichotomy seeps into the narrative itself and is visible in the very structure of the episodes. Often scenes in the Senate or in sumptuous patrician villas, which are the symbolic powerhouses of the Roman Republic, are followed by street shots or scenes set in middle-class dwellings like Vorenus' home (for example in episodes $5,6,7,9,10,11$ ) and even in the slums on the Subura (episode 2), where historically people lived in conditions of abject poverty in apartment blocks that were six or seven stories high and which was also one of Rome's most famous red light districts. However another form of duality is also to be found within the very walls of the corridors of power themselves: "as high flown as the rhetoric was, the senators were also willing to pull out knives and kill each other when the need arouse ${ }^{29}$ " like common thugs. Caesar's bloody assassination in the Senate by immaculately togaed fellow senators (in episode 12) is a case in point, and the beautiful palaces are also occasionally used throughout the series as ugly torture chambers, where people are flogged and/or raped ${ }^{30}$. The series pointedly tries to picture both sides of the same buildings, suggesting that the educated, refined Patricians are in fact just as ruthless and violent as the Plebs they so despise.

A similar point had already been made in I, Claudius where the halls of the marble palaces are just as dangerous (or even more so) as the battlefields or the unseen slums. Numerous characters are poisoned, stabbed, etc. there and the palace is used as a brothel by the mad emperor Caligula (episode 10), by Claudius' own wife Messalina for a "night of love, a tournament of sex, (...) copulation on a cosmic

\footnotetext{
${ }^{26}$ Bataille, p. 235

${ }_{27}$ Pierre Sérisier ("Rome, une série hors-norme," http://seriestv.blog.lemonde.fr/2009/05 27/rome-une-serie-hors-normes/), who is quite enthusiastic about the series ("L'ambition de Rome n'était pas de réussir une reconstitution fidèle des événements, mais à travers le prétexte de l'Histoire de décrire une atmosphère, une manière de vivre et des mœurs, celles qui existaient à Rome à cette époque. De ce point de vue, la série est une magnifique réussite "), also notes that "certains acteurs majeurs sont ignorés en particulier dans le conflit entre les optimates et les populares."

${ }^{28}$ See Yann Le Bohec, ROME. Un conte d'amour et de mort, Paris, PUF, 2013, p. 54, 70.

${ }^{29}$ Bruno Heller in the bonus DVD.

30 The most graphic example is probably the torture of Servilia by Timon in Atia's house in episode 4 of the second season.
} 
scale" (episode 12), while the Capitoline temple itself is the setting of what is perhaps the most gruesome scene of the series (not to be found in Graves' novel) when Caligula, believing he is Zeus, rips open his sister's belly and eats the fetus of their unborn child (episode 9) ${ }^{31}$. In turn ordinary soldiers do not hesitate to kill Caligula's baby daughter and her mother (episode 10), and in a previous episode Sejanus' children are also murdered, the little girl being raped beforehand to comply with Roman law which prohibited the execution of virgins, as the centurion explains (episode 8).

Thus acts of horrific brutality are committed throughout the two series. This violence however is not gratuitous. Both I, Claudius and Rome play on deliberate dissonances between the values of our world and that of Ancient Rome. The world of Rome being depicted is that of a harsh, pagan, pre-Christian society with a strong moral code which is in a complete contrast of our own, a society where compassion, mercy and pity were seen as weaknesses, not virtues, where might was right and where the institution of slavery, for instance, was seen as totally normal and was never questioned. I, Claudius however, favours the telling over the showing as violent scenes most of the time take place off screen and are suggested or reported rather than acted out on screen. For example, young Claudius is the laughing-stock of his entire family because he does not like watching the bloody games that the Romans enjoyed so much and he even faints during the first fight in the games dedicated to his father Drusus (episode 4). The viewers are made to share Claudius' distaste as the camera zooms in on his face: they are not shown the spectacle in the circus and the presence of a huge crowd "is suggested by sound effects ${ }^{32}$ ". This choice was probably financial as well as aesthetic: the limited budget of the series would have made it impossible to film spectacular scenes (battles, gladiatorial games and such like) "peopled by vast crowds, and accompanied by special effects 33 " which were typical of cinematic peplums.

In Rome on the contrary the spectators are extensively treated to Pullo and Vorenus' bloody exploits in the arena (episode 11), reminiscent of scenes from the film Gladiator (dir. Ridley Scott, 2000)34. The director and the historical consultant, as well as some of

\footnotetext{
${ }^{31}$ This particular scene was almost immediately removed from the master tape: "BBC management got cold feet about this specific shot and edited it out prior to the repeat in the same week," the producer of the I, Claudius DVD recently said (Radio Times, "Censored 1970 cuts to I, Claudius", 15-21 June 2013, p. 157), and in the closing seconds of episode 9, instead of the door swinging open to reveal the gruesome scene, the camera pulls away, leaving the spectator to imagine "the horror, the horror", as Conrad's Marlow would say.

${ }^{32}$ Joshel, p. 102

33 Joshel, p. 120.

${ }^{34}$ Vivien Bessières contrasts the representations of the topos of the gladiatoral games in the arena in Gladiator, I, Claudius, and Rome: "Dans Gladiator et dans le péplum en général, on ne voyait que l'arène, avec de rares contre-champs sur certains personnages du public.
} 
the actors, repeatedly say in the bonus DVD how, thanks to the series, their immersion into that pagan, albeit fictional, world made them realize how much our Western world today is both totally impregnated with and repressed by Judeo-Christian morality. According to Jonathan Stamp, in order to try and understand ancient Rome, the viewers have to free themselves from their Christian point of view, which they are steeped in, whether they are aware of it or not, and which is totally foreign to the world of ancient Rome. Thus there is an explicit pedagogical aim to the series which the director explains in the bonus: to make the audience understand how different that world was from theirs, something previous films and series did not seem to do at all or to do enough because, Stamp says, they took a "pastiche approach" to the period and "overlaid a modern morality on top 35 ".

Thus the directors, producers and screenwriters of Rome have a common goal: to attempt to go back to pre-Judeo Christian values. This is also very clear in the way religion is depicted. The characters in Rome seem to have a fairly contradictory attitude to religions. On the one hand, the Roman clergy is somewhat traditionally seen as greedy and corrupt, both by the upper classes (Caesar himself bribes the chief haruspex in episode 4) and by the people. Pullo in particular makes no bones about what he thinks of the established religion in general: "Priests, crooks many of them. I just talk directly to whatever god I'm doing business with. Bugger the priests" (episode 2). On the other hand the series clearly shows that "religion is everywhere in Rome, part of everything you do from the moment you get up in the morning to the moment you go to bed at night but religion has nothing to do with morality36", contrary to Christianity. The depiction of various Roman religious rituals is also carefully orchestrated to highlight their - to us - outlandishness. For example, as early as episode 1 the viewers are shown the spectacular ritual associated to the cult of Cybele, the Great Mother, when the Patrician Atia goes and prays the Goddess for the safety of her son Octavian, who has gone missing in Gaul. It involves chanting, self-castrated priests, the sacrifice of a black bull and a blood

Dans I, Claudius, on ne voit plus que les gradins. Dans Rome, on voit presque autant les deux, jusqu'à leur entrelacement, quand Vorenus fait irruption, depuis les gradins, dans l'arène." (Bessières 2013, p. 122). In an earlier article, he had propounded a detailed analysis of the same scenes in Gladiator and Rome, stressing the difference in their treatment on TV and at the cinema: "Ce qui diffère [...] du film à la série, c'est la nouvelle découpe faite dans le réel : non pas que l'un soit plus réaliste que l'autre, mais la série traite un autre champ du réel que ne traitait pas le cinéma : le champ du familier, du quotidien, du commun. Du film à la série péplum, nous passons d'un réalisme de l'événement spectaculaire, centré sur le héros, à un réalisme du quotidien familier, centré sur une communauté, ici une ville antique, représentée par le trajet des deux héros, mais aussi par toute une série d'autres personnages, fictifs ou historiques." (Vivien Bessières, "Rome : un péplum enfin réaliste ?” in Les Séries télévisées américaines contemporaines : Entre la fiction, les faits, et le réel, TV/Series \#1, juin 2012, p. 58)

35 Jonathan Stamp in the bonus DVD.

${ }^{36}$ Bruno Heller in the bonus DVD. 
bath ${ }^{37}$. The cult bestowed by lower-class women like Niobe (Vorenus' wife) to Bona Dea, the Good Goddess, represented by an enormous body painted woman sitting naked in the street and receiving small offerings on behalf of the goddess, is also briefly represented. The noble Servilia's elaborate ritual Egyptian cursing of Caesar, who has abandoned her (episode 5), is quite impressive as well, as is Octavian in his role as Pontifex painting Caesar's face red just before his triumph with the blood of a freshly sacrificed bull (see plate 4).

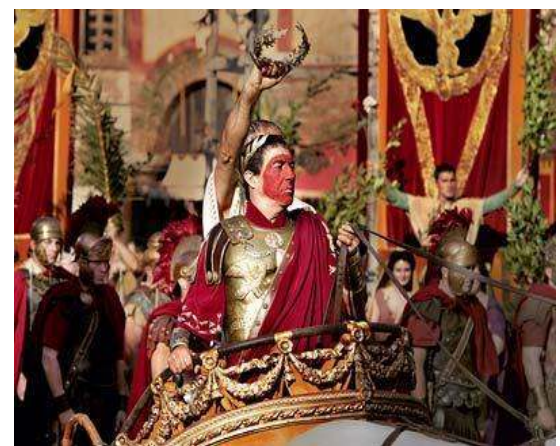

Plate 4. Rome, Caesar's triumph, season 1, episode 12 (source: duke.edu.)

And in keeping with the series' cosmopolitan view of Rome, other religions are also seen as an integral part of Roman life: Judaism, for example ${ }^{3}$, and even Hinduism.

By comparison, Roman religion in I, Claudius is shown as much tamer and more familiar: the apparition of the Sybil in the first and last episodes is in fact a literary device to explain how Claudius' memoirs will eventually be read almost two thousand years after they were supposedly written and hidden away. Her prophecy at the beginning establishes that Claudius, in spite of everything, will survive to become emperor and at the end (see plate 5) rounds off the story by telling the dying Claudius - and the audience - what will happen next: Nero's accession to the Imperial throne, his murder of Britannicus and his own mother, etc.

\footnotetext{
${ }^{37}$ This is the only religious ritual depicted in the series that the French historian Yann Le Bohec who, contrary to other French academics like Florence Dupont, actually admits that he enjoyed the series, considers as fairly accurate: "Un 'taurobole', toutefois, est représenté avec assez de vraisemblance, avec beaucoup de sang" (Le Bohec p.46). He finds the other rituals shown laughable and verging on the ridiculous: "faits d'un tiers de grand guignol, d'un tiers de christianisme fantasmé et d'un tiers d'animisme papou." (Ibid.)

${ }^{8}$ Timon, a horse-trader who becomes one of Atia's lovers and hired swords, is Jewish. In the second season, under his brother's influence, he (re)discovers his Judaism and even participates in revolutionary activities, and in episode 8 of the second series he and his family leave Rome for Judea.
} 


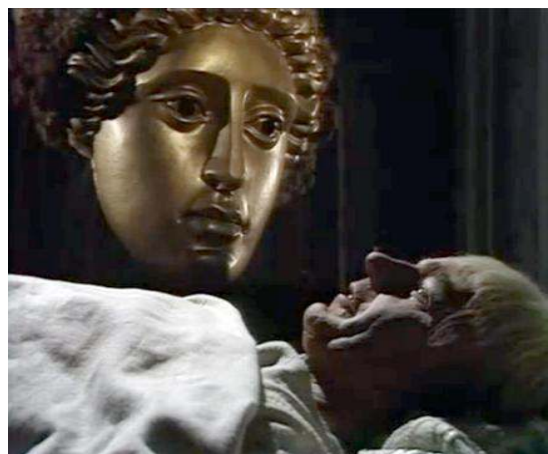

Plate 5: I, Claudius, the Sybil and the dying Claudius, episode 13 (source: kcet.org)

The other references to Roman religion are fairly occasional and always confined to the upper classes and more specifically the imperial family: in episode 3 for example, a haruspex witnessing an eagle dropping a wolf-pup into young Claudius' lap interprets the event to his incredulous and mocking family as the promise that Claudius will one day be Rome's protector (Rome is of course symbolized by the wolf). In episode 7, Livia on her death-bed makes Caligula and Claudius promise that when they become emperor they will make her a goddess so that she can escape punishment in the after-life for the numerous crimes she committed during her mortal life. The viewers do not get the sense of the omnipresence of religion throughout all the social classes which Rome conveys so successfully. Moreover, Christian morality and symbols sometimes seem to pervade the series: for instance, in the credits the serpent slithering across the mosaic of Claudius (plate 2) is clearly endowed with negative Christian symbolism (treason, danger...) whereas in ancient Rome the serpent was seen as a positive spirit. The only other religion represented in $I$, Claudius is Judaism, which Herod Agrippa, a childhood friend of Claudius', and King of the Jews, embodies as he occasionally explains to the amazed Romans the tenets of his monotheistic religion. However Judaism is mainly seen as the origin of Christianity: in the final episodes, discussions about the coming of the Messiah become more and more frequent, as first Caligula, and then Herod himself believe they are this Messiah (episode 12). Of course both false Saviours die a violent death as they repeatedly violate the First Commandment ("Thou shalt have no other gods before me"), as well as most of the others. Herod's conviction that he is indeed the Messiah leads him to revolt against Rome and to betray his old friend Claudius, who is left wondering as to this Saviour's coming and identity. 
One aspect shared by I, Claudius and Rome is their representation of women, who appear very little in the history books of that period, which were all written by men. Bruno Heller states that he wanted to put women back in history, pointing out that women were "incredibly powerful" in ancient Rome, partly because the men were always away. By comparison with other cultures in the ancient world, they had more freedom and latitude and, generally speaking, more of a life outside the confines of the home. Women certainly have very important roles in both series but whereas in I, Claudius they, like the men, all belong to the ruling elite 39 , in Rome women of all classes of society have a part to play in the plot: Queen Cleopatra, the Patricians Atia and Servilia, the Plebeian Niobe, and even Servilia's personal slave among others. However, they are all seen mainly in their traditional role of mothers ready to do anything to secure their sons' future: in $I$, Claudius, Livia is the arch-manipulator and villain ("always scheming", Claudius says in episode 1) whose sole agenda is to get her reluctant son Tiberius to succeed Augustus. She is eventually successful, poisoning in the meantime a large number of rivals and in the end Augustus himself (episode 5). The same story repeats itself a few generations later with Agrippina, who also poisons her husband Claudius to make sure her son Nero becomes emperor (episode 13). As for Octavian's mother Atia in Rome, "everything she does she is doing for the good of her family, for the good of her children, however evil it gets $4^{40}$." For her part Niobe readily lies to her husband (episode 2) to save the son she had with her brother-in-law while Vorenus was away in the army. For the women of Rome (Atia and Cleopatra in particular) sex or, in the case of Livia and Agrippina in I, Claudius, poison, is a means to that end, for they have no official political power and so resort to sex to manipulate men. Livia's declaration on Augustus' death-bed sums up her resentment, even if it must be taken with a very large pinch of salt:

LIVIA. You should have listened to me more... I've been right more often than you have but because I was a woman you pushed me into the background. And all I ever wanted was for you and for Rome. Nothing I ever did was for myself. Nothing. Only for you and for Rome. (episode 5)

She takes up the same point in a discussion with the young Claudius: "They won't allow me in the senate because I'm a woman and they won't allow you because you are a fool" (episode 5). The treatment of imperial women in the series is ambiguous, to say the least, and as Maria Wyke points out, "Livia's pseudo-feminist complaint [...] that

39 The one exception might be the low born Calpurnia, a recurrent character, a prostitute who is a loyal friend to Claudius and is given the thankless task of informing him of his wife's deceits (episode 12).

$4^{\circ}$ Jonathan Stamp in the DVD bonus. 
her capacities for government had been overlooked because of her gender" is somewhat undermined by the fact that it is "delivered at the very moment viewers observed the fatal poisoning of her husband 41 ". Messalina, Claudius' third wife, has political ambitions too but, unlike Livia and Agrippina, does not seem to care greatly for her son Britannicus. When her own mother rebukes her, saying: "I don't know why you want to concern yourself so much with matters of state. It's not a woman's place," she answers: "It may not be yours, mother, but it's mine" (episode 11. The exchange is not to be found in Graves' Claudius the God). Messalina is one of the more complex female characters of the series and is not only portrayed as the sex-crazed wife of poor, trusting old Claudius that Suetonius, for one, described. For her, as perhaps for the hippie generation of the 1960 s and 1970 s who watched the series, sex seems to be a means to open wide the doors of perception: "when I make love", she says, "I reach for something men never dream of" (episode 12). However, in the series as well as in the novel,

Messalina is here located within a feminine genealogy of sexual and political perversity in the Julio-Claudian family, headed by the literally poisonous Livia (wife of Augustus), followed most notably by the licentious Julia (daughter of Augustus) and Livilla (sister of Claudius), and completed by 'Agripinilla' (last wife and murderer of Claudius) ${ }^{42}$.

It seems that the contemporary debates on feminism are also at stake in the characterization of Messalina in particular, for British as well as American viewers: “television's Messalina as a kind of Woman's Libber hyperbolically constructed as hell-bent on political power and sexual revolution" could be read by Americans as "an educative indicator to the threat contemporary feminism posed to the nation 43 " and by British audiences as a warning against "the dangers of transgressive femininities," and "the proportionally extravagant punishment of the meretrix Augusta provides a history lesson in how to counter challenges to conventional femininity and restore 1970s Britain to social order44": in that respect, it seems that the series' outlook on women and feminism is definitely conservative.

As Sandra Joshel points out, "the television series generally reduces [Claudius'] reign to the stories of his wives, especially Messalina, whose adulteries and plots occupy two of the three episodes

${ }^{41}$ Maria Wyke, The Roman Mistress. Ancient and Modern Representations, Oxford, OUP, 2002, p. 384

$4^{2}$ Wyke, p. 357

43 Sandra Joshel quite convincingly argues that the New Right routinely blamed the feminists for the "coming apart of American power abroad" (in Vietnam), of "American society at home" (the various civil rights movements and the Watergate scandal) and, more generally, of "a masculine maintenance of power" by attacking the traditional family values and "emasculating the father/husband," Joshel, p. 128-129.

44 Wyke, p. 384, 388, 389 . 
devoted to his rule," and "the difference here between television and literary text is symptomatic of the reshaping of the imperial story45." Whereas in Claudius the God Graves "details Claudius's official acts, imperial administration, and wars at the borders of empire, especially the conquest of Britain" and "only the last 67 pages of the 507-page novel focus exclusively on the machinations of Claudius's wives ${ }^{46}$," the proportion is totally reversed in the series. For Joshel, only the familial aspects of Graves' story are retained in the series, transforming Roman history into a kind of soap opera 47 focusing on family scandals and the various sexual adventures of its members, especially the women (in particular Julia, Livillia and Messalina) who are seen in the series as much more debauched than they are in the novel.

The way in which sexuality is depicted in the two series is perhaps the greatest illustration of the thirty-year gap between them. In I, Claudius even the orgies are relatively quiet affairs. There is no nudity for example, and when Julia or Messalina and their "guests" really start engaging in nocturnal festivities there is a rather coy fade out and what happens next is mainly left up to the viewers' imagination 48 . Homosexuality is hardly alluded to: there is just a very brief scene in one of Julia's "parties" in episode 3 when two men are glimpsed kissing. The series was, after all, adapted from novels written in the 1930 s and aired in primetime on public television at a time when homosexuality was still considered as a criminal act49. Sexual deviations like brother-sister incest on the other hand are explicitly referred to in both series: in I, Claudius Caligula's obsession with his sister Drusilla from childhood onward is seen as a sign of his madness and depravation and in Rome, Octavian's adolescent desire for his sister (episode 9) is an early portent of the perverted nature of the future emperor 50 .

45 Joshel, p. 142.

${ }^{46} \mathrm{Ibid}$.

${ }^{47}$ This is also Florence Dupont's contention about Rome, which, as Sandra Joshel does with I, Claudius, she compares to Dallas ("L'antiquité falsifiée. 'Rome', ton univers impitoyable," Le Monde Diplomatique, avril 2007, p. 31). Florence Dupont's harsh criticism of Rome has been in turn criticized by many French classical scholars, such as Yann Le Bohec and Michel Eloy, as well as screenwriters Denys Corel and Antoine de Froberville and "sériephile" journalist Pierre Sérisier. Most experts on Ancient Rome seem to think that the series does a fairly good job at recreating the end of the Republic, give or take a few anachronisms (especially in the second season); see for example Florence Broizat, "La véritable histoire de Rome", Télérama $\mathrm{n}^{\circ} 2998,27$ juin 2007: "quelques infidélités historiques, mais des moeurs conformes à la réalité." (p. 26).

$4^{8}$ Once again, the series goes farther than the novel: "Graves devotes a relatively small number of pages to unchaste and manipulative wives. In fact, although Graves notes cases of female sexual misbehavior, he stages no scenes of sexual excess.” (Joshel, p. 123)

49 The Sexual Offences Act of 1967 had provided for a limited decriminalisation of homosexual acts in England and Wales but all homosexual behaviour was illegal in Scotland and Northern Ireland until the early 1980 s.

${ }^{50}$ In season 2, he tells his wife Livia that he will occasionally beat her because it arouses him. 
Generally speaking, the treatment of sexuality in Rome is in keeping with the producer's professed desire to go back to a preChristian worldview: if sex is omnipresent in the series, if sexual scenes are explicitly depicted and if full frontal nudity, both male and female, is occasionally shown, it is not only to pander to the $21^{\text {st }}$ century audience's expectations and tastes. One example is the scene in episode 6 where Octavian is watching his mother having her bath. It establishes how very different from ours Roman attitudes were to nudity and what we would see as (lack of) physical modesty. Contrary to JudeoChristian principles, the series emphasizes that sexuality was in no way linked to $\sin ^{5^{1}}$ and that nudity and more generally the body was nothing to be ashamed of in ancient Rome. The same can be said about privacy: Atia, for example, has slaves fanning her or handing her water to drink while she is having sex with her different partners (for example with Antony in episode 6). Moreover, according to the series' consultant historian, the Romans' theory on sexuality (if they had one) was in total opposition to the Judeo-Christian guilt-ridden attitude to sex: a lot of characters (Antony, Servilia, Octavia in episode 7) are actively bi-sexual, even if female homosexuality is much more openly depicted than male homosexuality ${ }^{2}$. Atia, herself Antony's mistress, has no qualms about offering her daughter Octavia to Pompey, in the hope of securing a profitable political marriage, and encouraging her son Octavian to become Caesar's lover to ensure her family's continuous prosperity.

For the producer and screenwriter of Rome, it is this total freedom from Judeo-Christian guilt feeling as far as sex and violence are concerned which makes the series so fascinating, because, he says, "the Romans are ourselves unleashed" and "the fun and kick" the viewers get from watching (and himself, he admits, from writing) is in fact a very direct form of wish fulfillment. For him, the attraction of that world of Rome is "that they are us, but us completely free to do as we wish". "It is difficult to feel superior to the Romans because they were so brutal and violent," he continues, "because really they are just doing what we would do if we had the chance53". The situation is totally different with I, Claudius, and there are in fact more common points between this series and Les Rois Maudits (ORTF), broadcast on French

\footnotetext{
${ }^{51}$ Yann Le Bohec concurs: "de nombreuses sculptures et bien des textes montrent une approche de la sexualité bien différente de celle qu'ont imposée les religions monothéistes depuis vingt siècles"(p. 133), even though he points out that, in fact, "les nobles et les intellectuels veillaient au plus haut point à la maîtrise de soi et la philosophie, le stoïcisme, à la mode juste après cette guerre civile, et le néo-platonicisme devenu dominant au III siècle, incitaient les hommes à une relative chasteté." (p. 134)

52 "[L]es réalisateurs auront tout de même moins de mal à filmer des scènes d'amour entre femmes qu'entre hommes. La caméra s'attardera ainsi sur les relations amoureuses entre la sœur d'Octave et la concubine de César, Servilia. Elle passera rapidement sur une scène de sodomie aux motivations plus intéressées." (Bessières 2013, p. 123)
}

53 Buno Heller in the bonus DVD. 
television in 1972, than between I, Claudius and Rome: both are typical TV products of the 1970s, are also extremely well played, were written for public television with a mission to entertain, but also to educate the viewers - tastefully. Both also share a similar vision of history as the more or less exclusive story of great men and great families: the JulioClaudian emperors of Rome for the first one, the Capetian kings of France for the second, with very little consideration for the people they ruled over.

The three series however, in spite of their conceptual differences, share a common belief that, however different the historical context might be, basic human relationships do not change and human emotions remain constant throughout the centuries. This is what makes it possible for $21^{\text {st }}$ century viewers to feel that they can identify with the protagonists who are after all seen as not very different from them ${ }^{54}$. This form of historical fallacy in I, Claudius is denounced by Sandra Joshel: according to her, Robert Graves himself, but also John Mortimer, who wrote a play based on the novels, Tony Richardson, the director of Mortimer's play, as well as Jack Pullman and Herbert Wise, respectively the series' screenwriter and director, all found "the Romans familiar," and for the critic "perceptions of familiarity bring in their wake the danger of similarity55." This means of course a somewhat biased and sometimes even twisted interpretation of history and historical characters: for example, Atia, Octavian's mother, is portrayed in Rome as a totally amoral manipulator whereas Tacitus in his Dialogus de oratoribus (XXVIII) praises her as an ideal Roman matron and in I, Claudius Claudius himself, presented as "a shambling imbecile" in the Latin sources, is turned by Graves into "an engagingly self-deprecating yet principled narrator 56 ". As Florence Dupont has pointed out, however, more than

54 This "anthropological error" in Rome is also condemned by Vivien Bessières : "les intentions réalistes de Rome échouent non seulement parce que la série accumule les erreurs factuelles, historiques, mais aussi et surtout à cause de l'erreur anthropologique qui consiste à gommer les différences entre l'homme de la Rome antique et l'homme des EtatsUnis modernes." (Bessières 2013, p. 114). Yann Le Bohec concurs : "[Les créateurs de Rome] ont plus ou moins transposé dans l'Antiquité et dans la Méditerranée des préoccupations proches du XXI'̀ siècle et des pays de l'Atlantique .... peut-être par le désir plus ou moins conscient de faire croire [aux téléspectateurs] que les Romains étaient plus proches d'eux qu'ils ne l'étaient en réalité." (Le Bohec, p. 17).

55 Joshel, p. 126, 150

${ }^{56}$ Robert Graves' novels constitute in themselves "a highly idiosyncratic, revisionist history of Claudius' early life," Wyke, p. 355. Wyke also reminds the readers and the viewers of $I$, Claudius who might be in search of what the "real" Messalina was like "of the dominating position Graves' novels have held (and continue to hold) in the Anglo-American popular production and consumption of the meretrix Augusta," p. 353. She points out that the caption of the webpage of the I, Claudius project, "set up in January 1999 through the department of classics at St Anselm College in new Hampshire, USA, as part of a student project to analyse and evaluate the British television serial” (p. 352), depicting Messalina as 
the occasional anachronism, the vision that they convey of human nature as never changing is perhaps the greatest falsification of them all.

\section{Bibliography}

BATAILlE Sylvaine, “Haunted by Shakespeare: HBO's Rome," Television Shakespeare. Essays in honour of Michèle Willems, Mont-SaintAignan, Publications des Universités de Rouen et du Havre, 2008, p. 219-249.

Bessieres Vivien, "Moi, Claude et Rome: étude comparée de deux séries,” Journée d'étude sur le péplum, jeudi 24 mars 2011, Université de Pau et des Pays de l'Adour,

http://crphll.univpau.fr/live/archives/journee-

etude_peplum/BESSIERES+Vivien, consulted in September 2014.

Bessieres Vivien, "Rome: un péplum enfin réaliste ?" in Les Séries télévisées américaines contemporaines : Entre la fiction, les faits, et le réel, TV/Series \#1, juin 2012, p. 51-60, http://revuetvseries .wix.com tvseries, consulted in August 2013.

BESSIERES Vivien, “'Rome, Sweet Rome’ : L’idée américaine du foyer dans la série Rome," Les séries américaines. La société réinventée ?, Paris, L'Harmattan, 2013, p. 113-130.

BRoIzAT Florence, "La véritable histoire de Rome," Télérama ${ }^{\circ} 2998$, 27 juin 2007, p. 26-28.

CESAR, Guerre des Gaules. Livres V-VIII, traduction L.-A. Constans, Paris, Les Belles Lettres, 1972.

COREL Denys and Antoine de FROBERVILLE, “'ROME” ... Malheur à celui qui n'a pas compris. De la confusion des genres entre fiction et Histoire," Struggling Writer, blog de Denys Corel, 4 juin 2007, http://denyscorel.over-blog.com/article-10713193.html, consulted in September 2014.

CHANDlen Raymond, "The Simple Art of Murder," The Atlantic Monthly, December 1944, p. 53-59.

"nothing but a tramp" "neatly summarizes the characterization of the televisual Messalina inherited from Robert Graves's twin narratives.” (p. 354). 
DuponT Florence, "L'antiquité falsifiée. 'Rome', ton univers impitoyable," Le Monde Diplomatique, avril 2007, p. 31.

Eloy Michel, "Rome, l'unique objet de mon assentiment...," http://www.peplums info /pep 39r.htm\#ox, consulted in September 2013.

GALLEGo Julie, "Jules César au secours des scénaristes américains : l'incipit de la série Rome," in Les Séries télévisées américaines contemporaines : Entre la fiction, les faits, et le réel, TV/Series \#1, juin 2012, p. 25-50, http://revuetvseries.wix.com/tvseries, consulted in August 2013.

Graves Robert, I, Claudius (1934), Harmondsworth, Penguin, 1955.

Graves Robert, Claudius the God (1934), Harmondsworth, Penguin, 1977.

Joshel Sandra, “I, Claudius: Projection and Imperial Soap Opera," in Imperial Projections: Ancient Rome in Modern Popular Culture, Baltimore and London, John Hopkins UP, 2001, p. 119-161.

LE BoHec Yann, ROME. Un conte d'amour et de mort, Paris, PUF, 2013 .

SERISIER Pierre, "Rome, une série hors-norme," 27 mai 2009, http: /seriestv.blog.lemonde.fr/2009/05/27/rome-une-serie-hors-normes/, consulted in September 2014.

Wyke Maria, The Roman Mistress. Ancient and Modern Representations, Oxford, OUP, 2002, p. 352-390.

DVD I, Claudius, BBC 1976, dir. Robert Wise, scr. Jack Pulman, with Derek Jacobi, Sián Philips, Brian Blessed, George Baker, John Hurt..., Dutch FilmWorks B.V., distributed by Moviepower, 2004.

DVD Rome, season 1, Warner Brothers 2005, with Kevin McKidd, Ray Stevenson, Polly Walker, Ciaran Hinds... HBO Video, 2006.

I, Claudius Project, January 1999, http://www.anselm.edu/internet/ classics /i,claudius/, consulted in September 2013.

Isabelle Roblin is an Assistant professor at the Université du Littoral-Côte d'Opale. She specialises in contemporary anglophone literature. She is currently working on literary and cinematographic rewritings of the British and American literary canons and has published an essay on Harold Pinter's adapted screenplays. 
Isabelle Roblin est Maître de Conférences à l'Université du Littoral-Côte d'Opale, spécialisée en littérature anglophone contemporaine. Elle travaille actuellement sur les réécritures littéraires et cinématographiques des canons littéraires britannique et américain, et a publié un ouvrage sur les scénarios d'Harold Pinter. 